\title{
Tudatos elhatárol(ód)ások: Megismerés, viselkedés és erkölcs viszonya a kognitív etológia hauseri értelmezésében
}

(Marc D. Hauser: Vad elmék. Mit gondolnak az állatok? Vince Kiadó 2002. 388.o.)

Így hivatkozzon erre a cikkre:

Tófalvy Tamás. „Tudatos elhatárol(ód)ások: Megismerés, viselkedés és erkölcs viszonya a kognitív etológia hauseri értelmezésében”.

A folyóiratban közölt müvek

a Creative Commons Nevezd meg! - Ne add el! - Így add tovább! 4.0

0

Nemzetközi Licenc feltételeinek megfelelően használhatók. 


\title{
Tudatos elhatárol(ód)ások:
}

\section{Megismerés, viselkedés és erkölcs viszonya a kognitív etológia hauseri értelmezésében}

\author{
Marc D. Hauser: Vad elmék. Mit gondolnak az állałok?
}

Mára már szinte minden, az élet gyakorlati és elméleti kérdéseit vizsgáló tudomány kialakította a saját tudat-fogalmát a maga módján: a biológiától kezdve a pszichológián és filozófián keresztül a kognitív tudományokig (és ezek különbözô ágaiban, irányzataiban) eltérô definíciókkal és hangsúlyokkal találkozhatunk. Az állati tudat kérdésében mindazonáltal ma valószínúleg a kognitíy etológia az egyik „legkompetensebb” megközelítés, tekintve, hogy egy olyan integratív, tudományközi hozzáállást képvisel, ami a megfigyeléseken és irányított kísérleteken kívül figyelembe veszi a neuropszichológia, a fejlődéslélektan, sốt akár az elmefilozófia idevágó felismeréseit (vagy problémafelvetéseit) is (ld. Miklósi 2003). Ez a sokat emlegetett interdiszciplinaritás a Harvard Egyetem tanára, Marc D. Hauser könyvében is tettenérhetô: ha úgy tetszik, az állati megismerés általa preferált modellje az állatokra vonatkozik, de nemcsak az állatokról szól. Tág nézópontból kapunk sokoldalú áttekintést a könyvből, miközben sokat megtudunk az etológiai megközelítés elhelyezkedésérôl is a kognitív tudományon belül.

A könyv alcíme (What Animals Really Think) gyakorlatilag teljesen ellentétben áll Hauser célkitűzéseivel és munkamódszerével: a „Gondolkodnak-e az állatok?” kérdést a szerző már a bevezetésben értelmetlennek nevezi, és ennek szellemében mindvégig nem annyira a „mit”, mint inkább a „hogyan” vizsgálatával foglalkozik. Ettốl függetlenül érdemes megnézni, hogy a szerzô valójában miként fogja fel az állati viselkedés és a megismerés viszonyát. Hauser mint kognitív kutató és primatológus alapvetőnek tartja az állati elmék létét, túllépve az ezt tagadó behaviorista szemléleten, és ezzel együtt elutasítja a másik végletet, az anekdotikus természetû, antropomorfizáló álláspontot is, ami az emberi tudatállapotokkal analóg természetû jelenségeket tulajdonít az állatoknak (lásd Bekoff 1995a, 1995b), következésképpen számára az elme összetettségének foka, múködésének módja és funkcionalitása a fő kérdés.

A szerző felfogása szerint „....minden állat és az ember is három területspecifikus mentális eszközzel van felszerelve. Mindegyik mentális eszköz bizonyos szemléleti sémák szerint múködik, amelyek a világ statisztikai szabályszerúségeit tükrözik - a létező dolgok térben és időben összefüggenek; a fizikai tárgyak akkor és csak akkor mozognak, ha érintkezésbe kerülnek egymással; a tereptárgyak a térbeli környezet stabil jellemzôi." (301. p.) Az első kulcsfogalom-csoport, a mentális eszköztár tehát egy olyan univerzális készséget alkot, amiről Hauser (is) azt az evolúciós 
nézetet vallja, hogy nem veleszületett készség, csupán a három alapvetô mentális eszköz elsajátítását lehetôvé tevô tanulási mechanizmusok tekinthetôk genetikus adottságnak. Az elsố ilyen mentális eszköz a tárgyállandóság felismerésének képessége, amelynek evolúcióját Hauser áttekinti mind a törzsfejlődés (a fajspecifikus jellemzốk), mind az emberi egyedfejlődés (fejlôdéslélektani kutatások) felôl; az általa másodikként leírt mentális eszköz a számismeret, ami annyiban egyetemes, hogy spontán aránybecslés formájában az állatoknál és az embernél is megtalálható, szemben a kategória alapú absztrakt számolással, ami csak a felnôtt emberre jellemzô. A pontos számolási készség evolúciós magyarázatául Hauser szerint a cserekereskedelem megjelenése szolgálhat, ami erős szelekciós nyomást fejtett ki az egyre precízebb mennyiségek megállapítása irányában. A harmadik mentális eszköz a tájékozódás, ami például a helyzetbecslés vagy a kognitív térkép mechanizmusaival koordinálja az állati elme térbeli orientációját.

Mivel minden állatfaj - s így az ember is - rendelkezik ezzel az egyetemes mentális eszközkészlettel, ebbôl eredôen a megfigyelhetô eltérések nem minôségi, hanem csak fokozati különbségek, amelyek a sajátos ökológiai problémák és a társas lét következtében alakultak ki. Az tehát, amit ezzel kapcsolatban Hauser szemére lehet vetni, hogy „szemléltető példáiban” nemigen követi álláspontjának elvi univerzalizmusát, így nem minden esetben meggyôző, hiszen a legtöbb kétség természetesen azzal kapcsolatban merülhet fel, hogy valóban minden egyes eszköz megtalálható-e minden állatnál. A példák legtöbbje figyelmen kívül hagyja az úgymond „alacsonyabb rendû” állatokat, vagy ha mégsem, akkor olyan példákat kapunk, amelyek inkább jellegzetesek, mintsem általánosak. (Egy példát említve: a hangyák és a méhek híresen jól tájékozódnak, ezért a tájékozódásról szóló fejezetben szerepelnek, de azt nem tudjuk meg, hogy vajon „hogyan állnak” a számolással.)

A szerző ugyanakkor sok helyen meggyőzően vitába száll más álláspontokkal, például a Gallup által csimpánzokkal végzett tükrös önfelismerési kísérletekból levont következtetésekkel. Szerinte az önfelismerés nem feltétlenül bizonyítja az éntudat létét. A fó érve erre a prosopagnosia nevú idegrendszeri betegség, ami az alsó halántéklebeny sérülése esetén lép fel, és azt eredményezi, hogy a beteg képtelen felismerni az ismerôsöket az arcuk alapján, sốt, saját arcának tükörképét is idegenként éli meg. Ezzel együtt - mint Hauser rámutat - a beteg rendelkezik éntudattal, hiszen helyzetével tisztában van, és ez a tudat nagyon is frusztrálja.

Hauser hasonlóan érvel a Gergely és munkatársai (Gergely et al. 1995) híres kísérletéből levont olyan következtetések ellen is, amelyek azt feltételezik, hogy a csecsemők fokozott figyelme a szándéktulajdonítás képességének bizonyítéka. Hauser szerint ez nem így van: úgy vélekedik, hogy ez a reakció nem a pszichológiai, hanem a fizikai irracionalitásra adott válasz. Ebben az esetben azonban Hauser érvelésének természete már szükségszerűen lágyabb, hiszen a következtetések legfőbb (sokszor egyetlen) bázisát adó fixációs („odafigyelési”) idô - tekintettel arra, hogy amíg nem tudjuk megállapítani, hogy konkrétan „minek” is szól a figyelem, addig csak hipotézisekre támaszkodhatunk - maga is igen problematikus. Mindazonáltal Hauser szerint bizonyítottan a csimpánz, a törpecsimpánz, az orángután és az ember képes önfelismerésre (a szegény gorilla hiányzik ebbốl a sorból...), ám éntudattal csak a kétévesnél idősebb ember rendelkezik - bár még ma sem tudjuk, hogy az ember kivételességének ebben az esetben voltaképpen mi az oka. 
A továbbiakban szerzônk a megismerésnek a társas létből fakadó meghatározó tényezőire fókuszálja figyelmét: szó esik a szociális szerveződés és a kommunikáció evolúciójáról (lásd még ebben a témában: Hauser 1997), valamint az állati és az emberi közösségek között jelenleg fennálló különbségekról. Itt Hauser arra a következtetésre jut, hogy az állati és az emberi kommunikáció (a szavak, illetve a hangjelzések használata) alapvetően eltérő mentális eszközöket feltételez. A többek között cerkófmajmok és különbözô énekesmadarak körében végzett megfigyelések nyilvánvalóvá teszik, hogy azok kommunikációja egészen bizonyosan rendelkezik egyfajta szabályrendszerrel, de ez még korántsem szintaxis, hiszen csak korlátozott jelentéstartalmat hordozhat.

Hauser felfogása általánosságban jól illeszkedik az újabb posztkarteziánus kognitív szemlélethez: elveti az állati értelem és érzelem elválasztását, és a különbözô komplexitású mentális eszközök fogalmának bevezetésével „a nem minden tudatos, ami mentális tézise", valamint a társas megismerés elve mellett foglal állást. Ez azonban korántsem a teljes kép, hiszen Hausernál a legváratlanabb helyeken több mint meglepő kijelentésekkel találkozhatunk: például azzal, hogy „[az állatok]...Kafkateremtmények, tele gondolatokkal és érzésekkel, de híján vannak az olyan rendszernek, amelynek segítségével a gondolataikat valahogyan ki is fejezhetnék mások számára”. (272-273. pp.) Ezzel az alapvetően és jellegzetesen karteziánus gondolattal, miszerint a performancia és a kompetencia egymástól függetlenül létező, másmás természetû mentális jelenségek, Hauser ełlentmond saját általános felfogásának (és az evolúciós folyamatok logikájának), ami a készségek és a gyakorlatok egymást feltételezô rendszerében elméletileg sem hagy helyet efféle eltéréseknek.

Az alcím viszonylag jól kimagyarázható összeférhetetlenségével szemben az ilyen (és más, ehhez hasonló) ellentmondások már nem igazán menthetôk: úgy tûnik, hogy Hauser felfogása sok esetben sok kisebb részkérdésben nem a legmegfontoltabb, tehát egészében tekintve sem lehet az. Egy másik, már általánosabb ellenmondást jelent, hogy a szerző mindvégig evolúciós folytonosságról beszél, ám a jelentôsebb és a végső következtetéseit mégis az állatok és emberek közötti lényegi különbségekre alapozza.

E lényegi különbségek egyikére, amit Hauser a kuhni perszeverancia fogalmával fejez ki, egész koncepciót épít: „a kisgyermekek és az állatok képtelenek a konceptuális váltásra, $\mathrm{s}$ így képtelenek megérteni, miért alakultak ki, s néha miért változnak meg az absztrakt szabályok és elő́rások". (304. p.) A kuhni perszeverancia fogalmában egyrészt az lehet „gyanús”, hogy egy „lágyabb” szociológiai sémát alkalmaz egy „keményebb” pszichológiai jelenségre, másrészt a probléma természete alapvetôen másnak tûnik: a tudományos közösségek többnyire tudnának, de nem akarnak átlépni egy másik paradigma magyarázó rendszerébe, míg az állatok és a kisgyermekek esetében ez nem választás kérdése. Túllépve azonban a terminológiai kérdéseken, az a körülmény, hogy evolúciósan kifejlődhet a konceptuális váltásra való képesség, egyáltalán nem változtatja meg azt a tényt, hogy egy bizonyos egyed ettôl még nem képes erre. Így az újszerűnek beállított koncepció végül nem lesz más, mint egyszerú illusztrációja annak a jelenségnek, hogy egyes bonyolultabb magyarázatok bizonyos („megértô”) mentális komplexitás hiányában nem magyarázatok.

Az eddigiektôl eltérően inkább morális alapon tárgyalható legfőbb probléma a végsô, etikai jellegû következtetésekkel kapcsolatban merül fel: Hauser az utolsó fejezetekben - az altruizmus problémájából kiindulva - az állatok erkölcsi státuszát 
vizsgálja. Mint ismeretes, a „családon belüli” önfeláldozás problémájára a választ a gének szintjén lehet keresni, ellenben a más közösségekben megnyilvánuló altruizmus a kölcsönösség elvével és elvárásával magyarázható, és (többek között) játékelméleti kooperációs modellekkel írható le. (Hauser ezt a kérdést a vámpírdenevérek igen érdekes és bonyolult „vérátadási” technikájával szemlélteti részletesebben.)

Az altruizmusnak ez a mindenütt jelenlévố gyakorlata nyilvánvalóvá teszi, hogy az „etika” elsôsorban ökológiai fogalom, nem emberi találmány, azaz előbb volt a norma, azután a felismerése. Hauser az állati morál tárgyalásánál mégis az erkölcs egyfajta „filozófiai” meghatározásából indul ki, miszerint a norma tudatának megléte (az érzékelő és a reflektív tudat nem etikai alapon történő megkülönböztetését illetôen lásd Griffin 1992) a döntô: „Ha nincs elképzelés a normáknak megfelelő reagálásról és emóciókról, valamint a normaszegésrôl, akkor nem lehet szó morális rendszerrôl, így morális ágensekrôl sem" (327. p.). Ameddig azonban tényként fogadjuk el, hogy az emberi etika (normarendszer) csupán az előbb tárgyalt altruisztikus gyakorlat reflektálása, addig úgy tûnik, hogy a valójában antropomorfizáló helyett inkább az ökológiai szemléletbôl érdemes kiindulni. Bár Hauser valóban érzékletesen mutatja be, hogy az egyes különállónak vélt területeket (például az érzelmeket, az értelmet, a készségeket és az erkölcsi érzéket) nem lehet elkülönítve szemlélni, mégis kerülni látszik azt a körülményt, hogy bizonyos készségek szorosabban kötődnek egymáshoz, s így azokhoz az előfeltételekhez is, amelyek szerinte az erkölcsi rendszer kialakulásához feltétlenül szükségesek. Így nem tekinthetô bizonyítottnak az elme komplexitása és a morális státusz közötti általános összefüggés elmélete. Mivel a bizonyíték hiányát maga a szerző is említi, nyilvánvaló, hogy konklúziója nem eredmény, hanem állásfoglalás, és ebben a minôségében nem a legfelelôsségteljesebb.

Mivel minden empirikus kutatási eredmény implikál valamilyen (néha többféle) morális állásfoglalást, az ilyen vagy ehhez hasonló esetekben - vagyis választhatóság esetén, ha az empíria nem ad egyértelmú választ - célravezetốbbnek tûnik morális alapon dönteni. Ilyen módszertani gyakorlat alkalmazásával nemcsak hitelesebb lehet az elméleti keret, hanem elkerülhetôbbnek bizonyulhatnak az olyan lehetséges értelmezések is, amelyek legitimizálják az állatokkal mint másodrendû élőlényekkel való bánásmódot. (Ezek elől sajnos Hauser sem tér ki egyértelmúen, lásd 285. és 290. p.) Más szóval, ahogy de Waal (de Waal 2001:207) mondja: „Erkölcsösek az állatok? - Fogalmazzunk úgy, hogy az erkölcs tornyának néhány emeletén ók is ott vannak. Ha valaki még ezt a szerény javaslatot is elutasítja, az a szerkezet egészét sem láthatja a maga teljes szépségében.”

Tófalvy Tamás

Marc D. Hauser: Vad elmék. Mit gondolnak az állatok? Vince Kiadó, 2002

\section{IRODALOM}

Bekoff, Marc (1995a): Cognitive Ethology: The Comparative Study of Animal Minds. In: Bechtel, William and Graham, George (eds.): Blackwell Companion to Cognitive Science. Blackwell Publishers, Oxford. 
Bekoff, Marc (1995b): Cognitive Ethology and the Explanation of Nonhuman Animal Behavior. In.: J. A. Meyer and H. L. Roitblat (eds.): Comparative Approaches to Cognitive Science. MIT Press, Cambridge, MA.

Gergely Gy - Nádasdy Z. - Csibra G. - Bíró S. (1995): Taking the Intentional Stance at 12 Months of Age. Cognition, 56.

Griffin, Donald R. (1992): Animal Minds. The University of Chicago Press, Chicago - London. Hauser, Marc D. (1996): The Evolution of Communication. MIT Press. Cambridge Miklósi Ádám (2003): Az állati viselkedés kognitív etológiai értelmezése. In.: Pléh-KovácsGulyás (szerk.): Kognitív idegtudomány. Osiris, Budapest

de Waal, Frans (2001): Jótermészetűek. A jó és a rossz eredete az emberben és más állatokban. Mưszaki Könyvkiadó, Budapest 